\title{
Applying Routine Activity Theory: A Case Study of the Sonya Farak Drug Scandal
}

\author{
Nicole A. Shoenberger \\ Loyola University Maryland, Baltimore, USA \\ Email: nshoenberger@loyola.edu
}

How to cite this paper: Shoenberger, N. A. (2021). Applying Routine Activity Theory: A Case Study of the Sonya Farak Drug Scandal. Open Journal of Social Sciences, 9, 118-129.

https://doi.org/10.4236/jss.2021.910009

Received: September 16, 2021

Accepted: October 17, 2021

Published: October 20, 2021

Copyright $\odot 2021$ by author(s) and Scientific Research Publishing Inc. This work is licensed under the Creative Commons Attribution International License (CC BY 4.0).

http://creativecommons.org/licenses/by/4.0/ (c) (i) Open Access

\begin{abstract}
Sonja Farak was a chemist for a state crime lab in Massachusetts. She was arrested for tampering with evidence while abusing narcotics at work. Her arrest led to the dismissal of thousands of drug cases in Massachusetts. Given the account that Farak was a law-abiding citizen, it is questioned as to how an educated person with a stable job would commit a crime of this magnitude. Though Farak provided testimony of her behavior, no research has been conducted on the explanation for her crime. To examine her behavior, data from Farak's Grand Jury testimony are analyzed using a qualitative content document analysis. Examination of the data allows for the application of Cohen and Felson's Routine Activity Theory, which provides a theoretical understanding of Farak's evidence tampering and drug use. All three components (motivated offender, suitable target, and absence of a capable guardian) are presented. By doing so we get a better understanding as to how a law-abiding citizen, while participating in everyday routine life, can commit crime but remain undetected.
\end{abstract}

\section{Keywords}

Routine Activity Theory, Theory, Crime, Drugs

\section{Introduction}

In January of 2013, Sonja Farak, a chemist at a state crime lab in Massachusetts, was arrested for tampering with evidence related to criminal drug cases (Small, 2020). A year later, Farak pleaded guilty to tampering with drug evidence, theft of a controlled substance, and drug possession (Long, 2021). She received a sentence of 18 months with 5 years of probation and was released in 2015. Farak tested over 25,000 drug samples while working for the Amherst state lab (Grand Jury, 2015), and her confession led to the dismissal of thousands of drug cases in 
the state of Massachusetts (Becker, 2020).

Given the account that Farak was a law-abiding citizen, it is questioned as to how an educated person with a stable job would commit a crime of this magnitude. Though Farak provided testimony of her behavior, no research has been conducted on the explanation for her crime. To examine her behavior, data from Farak's Grand Jury testimony are analyzed using a qualitative content document analysis. Examination of the data allows for the application of Cohen and Felson's (1979) Routine Activity Theory, which provides a theoretical understanding of Farak's evidence tampering and drug use. By applying this theory to Farak's behavior, an understanding as to how a law-abiding citizen, while participating in everyday routine life, can commit crime but remain undetected.

\section{Literature Review}

\subsection{Routine Activity Theory}

Cohen and Felson's (1979) original Routine Activity Theory bridges three key components that when converged, increase the likelihood of crime. Specifically, for crime to occur, there needs to be a motivated offender who desires to commit the crime at the exact time the crime may take place, a suitable target which can be an object or a person, and the absence of a protector or guardian who can stop the crime from occurring but does not have to be a police officer (Cohen \& Felson, 1979). These components converge through a spatial-temporal routine (Cohen \& Felson, 1979), meaning it needs to be the right time and place for the crime to occur. Given the importance of the convergence, Felson and Cohen (1980) argue these events are not random. These crimes occur due to the daily social interactions and activities in which people engage in that may increase one's likelihood of victimization. Therefore, crime is a normal part of everyday interactions.

In addition to the three basic components, Felson (1986) added handlers as a potential deterrent of crime. A handler is associated with the motivated offender. Specifically, the handler tries to prevent the motivated offender from committing crime. A handler can be a parent, a spouse, or even a probation officer. The handler provides informal social control through emotional attachment or supervision (Felson, 1986). Through being emotionally attached to the handler, the motivated offender is less likely to commit a crime because they are concerned by what the handler may think or fear of losing the relationship (Felson, 1986). Further, if the handler is supervising the offender or is in close proximity to the offender, their presence could physically stop a crime from occurring (Tillyer \& Eck, 2011).

Felson (1995) further added the concept of place managers who are tasked with controlling a location. Their job is to control and maintain places. Place managers may be a landlord of an apartment complex, a supervisor at a restaurant, or a manager at a bank. Like a suitable guardian, an effective place manager may decrease the likelihood of criminal activity. 
Routine Activity Theory has been integrated with lifestyle-exposure theories (McNeeley, 2015). Advocates of the Lifestyle-Routine Activity Theory posit that a person's routine activities will differentially increase or decrease the likelihood of a criminal event (McNeeley, 2015). For instance, a person has a higher likelihood of victimization if they leave their house daily, drive through high crime areas, or go to work in lower income neighborhoods. Further, Lifestyle-Routine Activity Theory provides the backdrop for opportunity in the non-household events outside of the home have higher likelihoods of crime (McNeeley, 2015; see also Messner \& Blau, 1987). For instance, going to a concert or a sporting event provides increased opportunity for victimization compared to simply staying home.

\subsection{Application of Routine Activity Theory}

Despite originally being dismissed because of its simplicity (Eck \& Madensen, 2015), Routine Activity Theory is a widely used theory. One of the strongest applications of the theory is risky behavior and its association with increased victimization (see Sampson \& Lauristen, 1990; Kennedy \& Forde, 1990). Sampson and Lauristen (1990) found that regardless of major demographic correlates of crime, both minor and violent deviant behavior (theft, violence, drinking) increase the likelihood of personal victimization. Further, being in proximity to violence, such as a violent neighborhood, increases the likelihood of victimization (Sampson \& Lauristen, 1990). Overall, scholars have concluded teens that have more contact with other deviant kids, use alcohol or participate in other deviant behaviors, and frequent high crime areas, have a higher chance of being victimized than youth who engage in these lifestyle choices (Sampson \& Lauristen 1990; Kennedy \& Forde, 1990; Lauritsen, Sampson, \& Laub, 1991; Schreck \& Fisher, 2004; Wilcox, Tillyer, \& Fisher, 2009).

Cohen and Felson (1979) argued that it is not just about motivation, targets, and guardians. Crime increases as people engage in everyday situations that occur outside of the home (see also McNeeley, 2015). For example, Savard (2018) illustrated that routine behaviors which take place in certain locations outside of the home for women increase their likelihood of victimization. Specifically, women have higher likelihoods of victimization if they frequent "transit" locations such as public garages and parking lots or use public transportation. These specific locations, given the high frequency of people in one location, may foster an environment prone for crime (Savard, 2018). Therefore, if women are likely to leave their home and frequent a transit location during their daily routines, they are more likely to be victimized.

Less studied, but extremely useful for this study, is applying Routine Activity Theory to individual offending. Osgood and colleagues (1996) were pivotal in moving the discourse towards the motivation of the offender and applying the theory to individual offending. They examined the connection between unstructured and unsupervised socialization with peers, and its association to de- 
viant behavior by reconceptualizing the idea of suitable targets to mean "a deviant act [that is] possible and rewarding" (639). In this regard, there is a lack of capable guardians to supervise the unstructured behavior, there are no handlers to intervene, and being in proximity with peers provides a reward to engage in deviant behavior. Other scholars have found similar results and support the notion that deviant offending is more likely when a person is unsupervised (see Haynie \& Osgood, 2005; Osgood \& Anderson, 2004; Haynie, 2001; Wallace \& Bachman, 1991).

\section{Significance of Research and Research Question}

It is important to point out that Sonja Farak was considered a typical citizen as she did not fit the stereotype of a drug offender (Long, 2021). Farak was well educated, participated in sports, was married, owned a home, did not have a criminal record, and held a respectable job (Long, 2021). Cohen and Felson's (1979) theory is applicable to this scenario, as they argue that crime and victimization occurs during everyday "legitimate activities" (605). Crime does not have to occur in poor social conditions or neighborhoods. In fact, crime may increase during times of economic prosperity as there is more opportunity for motivated offenders (Felson \& Cohen, 1980). In this regard, the application of Routine Activity Theory to Sonja Farak helps us understand the research question, which is, how could everyday citizens, while participating in everyday life, commit crime but remain undetected? Though simple, understanding this research question helps provide evidence that both victimization and offending can occur in environments that are deemed safe and respectable. Crime does not only occur in dark alleys or at nighttime. Crime, in fact, occurs in all locations. Further, understanding Farak's motivation and ability to commit her crimes, helps to understand that those who commit crime are not necessarily "bad" people. Everyday interactions and situations increase the opportunity for crime to occur and various personal circumstances may increase a person's motivation to commit a crime.

\section{Methodology}

Farak's drug scandal occurred shortly after the arrest and conviction of another Massachusetts drug chemist, Annie Dookhan, who was arrested and convicted of falsifying evidence (Musgrave, 2019). It is speculated that Dookhan's conviction influenced how Farak's case was originally handled by the District Attorney. Given the media coverage of Dookhan, the District Attorney did not investigate whether Farak had committed crimes over the duration of her time as a chemist in the lab. Instead, the District Attorney only indicted her for the crime she was immediately arrested for, which was tampering with evidence in 2013. The diligence of state defenders who speculated that Farak's behavior was more than just the case in which she was prosecuted led to a larger investigation and eventually a Grand Jury in which Farak was offered immunity to testify about her entire 
drug use while working as a chemist for the state.

On September 16, 2015, Sonja Farak provided testimony to the Hampshire County Grand Jury under an Immunity Order. In this regard, Farak was to provide all evidence of her drug use and drug tampering while employed for the state of Massachusetts. In exchange for her testimony, she was provided immunity, which meant she would not be prosecuted for the information she provided (Grand Jury, 2015). If Farak chose to lie or misrepresent information she would have voided the immunity deal. Therefore, it is with moderate confidence that her testimony in 2015 is factual. Her Grand Jury testimony was made public and can be found online under the Hampshire County Court records.

Using Farak's grand jury testimony, a qualitative document analysis was conducted. A document analysis is a systematic qualitative research method technique for analyzing a document (Bowen, 2009). Within this technique, data are examined to interpret the meaning of the information and to organize the information into themes (Bowen, 2009). Documents can be extremely helpful in research, as some documents provide context of the event and background (Bowen, 2009). Therefore, document analysis is a useful technique to use for case studies where the researcher is analyzing a single phenomenon or event (Bowen, 2009).

To conduct the qualitative document analysis, a non-reactive document is selected. A non-reactive document is simply a document that cannot be affected by the researcher or the research process (Bowen, 2009). Given Farak's testimony is an official court document, the researcher has no ability to alter the document. The document was skimmed to gain an understanding of what was included in the court transcript. It was decided the court transcript contained important data that spoke to the application of the Routine Activity Theory. Direct sentences from the transcript were chosen as the unit of analysis. After this was confirmed, the transcript was read inductively two more times in order to identify categories of interest and potential emergent themes. Once emergent themes were documented, the data were scanned again to make sure internal homogeneity (everything in one category connects) and external heterogeneity (categories are independent of each other) were reached (Patton, 2002). By conducting this research method, a clear pattern of the application of the Routine Activity Theory became present.

\section{Results and Findings}

Three overarching themes are highlighted from Farak's testimony, which fit within Routine Activity Theory. The themes include: motivated offender, suitable target, and lack of capable guardian.

\subsection{Motivated Offender}

During the Grand Jury testimony Sonja Farak provided her reasoning and motivation for taking drugs, but also tampering with evidence. Her explanation il- 
lustrates her status as a motivated offender. Her motivation has two origins. Her original motivation stems from curiosity as she tried various drugs in college to help with her depression but never had the opportunity in her daily routine to use certain drugs like methamphetamines until she was employed at the Amherst state crime lab. Farak states,

I guess I was curious. For some reason even while I was in college as a freshman I-I was going through a rough period in my life like mentally and for some reason I had looked up drugs online and was reading about them and when I read about it I said like that's the one I would want to try if I was going to try it. It would give me energy and I liked the positive side effects of it I guess. It was a longer-it would-it would last a while. It was an energy boost but I never considered it. When I got to the Amherst lab I ended up seeing a meth standard that they had and one day I just decided to try a little bit (p. 58).

Farak stated that trying methamphetamines provided her with the intended effect she was looking for. This further increased her motivation to keep using the drug. In her testimony, she stated, "It gave me the desired effects. I felt amazing. It gave me energy. I felt more alert. I did not wish it but it gave me the pep I was looking for" (p. 60).

Her use of meth increased over time, and Farak soon became addicted to the drug. Her addiction meant her motivation to use and tamper with drug standards and evidence shifted from curiosity and the desire to increase alertness to needing drugs to function and perform at work. Farak mentioned a few times that if she stopped using, she would have withdrawal symptoms, her mood would change, she couldn't focus, and she would have to take off time from work. She stated,

I would go through some withdrawals ... It wasn't physical and what you think of with a heroin-opiate withdrawal of throwing up or anything but I became increasingly lethargic, tired beyond belief, wanting to sleep all day long. I could get bitchy for lack of a better word. I was very irritable and, I mean, there were times I took a couple days off from work just because I wasn't feeling like I could get up and go into work... I was having trouble focusing and even after those few days of extreme tiredness I would still have a lack of energy and it was a rebound effect (p. 64-65).

\subsection{Suitable Target}

By Farak's own account, she had never had the opportunity to use meth before working at the Amherst lab. Her daily routine never put her in the path of a suitable target. She admitted to being curious about using meth, making her a motivated offender; however, she needed access to a target. When working for the Jamaica Plain lab (her first job for the state), she didn't have access or opportunity to steal the drug since standards were locked and her job responsibilities and tasks did not give her the opportunity to test certain drugs. When she transferred to the Amherst lab, she had open access to various drugs; specifically, 
the meth standard ${ }^{1}$. She stated, "Our standards were stored in a couple different places. In the refrigerator there was probably 50 standards ... and in the filing cabinet there possibly were twice as many, a hundred" (45). The location of the refrigerator plays an important role in Farak's behavior since everyone in the lab had access to the standards. Further, the refrigerator of standards was located in the same lab that Farak was working and testing evidence.

Another important factor was the volume of the meth standard that was accessible to Farak. The meth standard was given to the lab because it was ordered by mistake by another lab, therefore, there was more meth standard than usual in the lab. As a result, there was a large quantity that Farak was able to use over a long duration of time. When she no longer could use that standard, she switched to other drugs standards such as ketamine; however, this did not provide the intended effect, as the duration of the effects wore off too soon.

Because the drug standards she had access to diminished, Farak eventually switched to another suitable target: tampering with evidence that had been seized during drug cases. Specifically, she started to use cocaine. Given the lab tested cocaine at a higher frequency, Farak could not use the standard as the reduction in the standard would be noticeable to those working in the lab. Instead, she would look for opportunities in which she was tasked with testing evidence presumed to be cocaine. Farak noted, "I guess I was concerned with the cocaine standard and the volume going down I guess. I had been assigned a sample from the USPS, the Postal Service, that was a large amount of cocaine and after analyzing it, I did take some off to the side for personal use" (p. 80-81).

The USPS sample was the first time she tampered with evidence; however, Farak admitted that she would purposely slow or speed her work if she knew a cocaine case was next on the docket to be tested. At this point, she was creating opportunities where she would have access to her target—evidence bags filled with cocaine.

Overall, Farak had multiple suitable targets during her time at the Amherst lab. She admitted to using multiple standards and eventually tampering with both cocaine and crack cocaine. Working at a lab that tests drugs provided a huge opportunity to encounter her desired target.

\subsection{Lack of Suitable Guardians}

The strongest evidence for Routine Activity Theory for the case of Sanja Farak is the lack of a suitable guardian to stop her from committing her crimes. Farak painted a picture of very lowkey atmosphere by stating, "there was a little less stress, more laid back. We all-it was one of the atmospheres if you got your work done there wasn't a lot of people stressing over you, looking over you" (p. 34-35). This laid-back atmosphere meant that Farak was often left unsupervised. Sometimes she would take the standards when "it was over lunch" or "someone

${ }^{1}$ Standards, as defined by Farak, are the pure substances in which the chemists would test the drug evidence against. 
may have been in the evidence office across the hallway" (p. 59). Because various employees were not present, Farak also admitted that she was able to "aliquot a small amount of the bigger vial to one of our sample vials. And so if they were to allow me to use it in private, I would use a small metal spatula that we had that we used to manipulate the powder and dip it in and since it was an oil it would kind of coat the metal spatula and I would lick it" (p. 61-62).

When questioned further about being alone in the lab, Farak explained,

I could be alone for a short period of time multiple times a week. You know, Sharon most of the time was across the hall. She did come over and bring, you know, certificates of analysis for us to sign and stuff over. Jim almost always left before me. I guess, depending on the day, sometimes Rebecca would-or two of us might have court and so one of us would be in the lab from, you know, noon to the end of the day by ourselves or like, you know, if one person's already left for the day, who else is gonna run across the hallway to return their submissions and get-take some more out. You know, that's gonna take at least five, ten minutes so if I was on the other side it afforded me the opportunity if I wanted to try to take another aliquot of some sample from the main stash, I could do that (p. 119-120).

Farak also detailed that when using crack that she started paying attention to who frequented bathrooms, which bathrooms weren't used. She also paid attention to whether they were single stalled restrooms. She admitted to sneaking

Across the hallway to the fume hood where I would smoke just because I could get rid of the smell, the smoke directly. If people weren't around I could pretty much - if it was the end of day and everyone had already left or their, you know, their shift was over or, you know, say Sharon left to go home early because it was a long weekend and she was packing, then I could normally smoke at my lab bench if I wanted to (p. 122-123).

Though there were a lack of suitable guardians watching over her behavior, the question becomes, did anyone notice samples being diminished or question her work? Farak describes a moment when her supervisor was conducting an inventory of the lab and she was concerned about the supervisor noticing the reduction of the meth standard. Farak added water to the standard; however, this causes a separation of the chemicals. When asked if she thought her supervised noticed, she stated, "He didn't notice that but due to the age of the sample and the fact that the seal-the thing that would help seal it was corroding, he assumed that it was just degrading, breaking down and so he basically got rid of it" (p. 66).

To extend suitable guardians, Farak also had an absence of a handler. It is known that her supervisor and her work colleagues did not suspect or inquire about her drug use; however, even her wife was incapable of noticing and intervening in Farak's drug use. Farak stated that she was known to have anger issues and depression, therefore, if she had erratic behavior, her wife would assume it was because of mental health issues. Farak stated, 
Besides having some depression issues and addiction issues, I have some anger issues so there were times she would see an erratic behavior and ask if I was on drugs and I would say no. Or whether-she occasionally wondered if maybe I was getting some weird contact high at work just being around drugs, poor ventilation, it's an old building but I told her no. We had this-I don't want to say joke-a long running joke that I had really bad PMS three weeks out of the month. But Pll say my anger issues started previous to any drug use, so there was no like boom, all of a sudden I was acting a certain way around her.

\subsection{Summary of Findings}

In sum, data show a clear illustration of Cohen and Felson's (1979) Routine Activity Theory. By her own testimony, Farak admitted she was a motivated offender as she acknowledged she wanted to try meth out of curiosity. This curiosity led to her becoming addicted to meth; therefore, her continued use of drugs out of fear of withdrawal was her secondary motivation. She provided much evidence in regard to having access to a suitable target. Her targets were the drug standards that were used for testing comparisons, and she had direct access to drugs that needed to be tested for evidence in drug possession cases. Lastly, Farak made clear that there was a lack of suitable guardians as she mentioned she was often left alone in the lab, she could leave her desk without question, and no one ever questioned her work. All three components of the theory are present and coincided at the same time, which increased the likelihood that a person, in their everyday routine, may commit a crime when the opportunity is presented.

\section{Discussion}

There is no question as to whether Sonja Farak abused her position as a chemist in a state lab to abuse drugs. As with many crimes, the question becomes why or how did these crimes occur? For Farak, we can apply the Routine Activity Theory to answer these questions. We are privy to her motivations, and we are aware of both the lack of suitable guardians and the access to a desired target.

Farak was clearly a motivated offender as she stated she had a curiosity to try drugs. By reading the court transcript, however, this motivation may have been strongly influenced by her ongoing mental health struggles. She outlined that she struggled with depression and even attempted suicide when she was younger. Given her mental health issues, her desire to try drugs may be more than just simple curiosity. It could be reasoned that her motivation could have been to lessen her struggles with depression, anger, and anxiety. To this point, it is important to note that a motivated offender might be motivated by multiple reasons or that their motivation is more complicated than simply to get high. In the end, Farak had to steal the drugs to lessen the likelihood of withdrawal; however, this becomes a secondary motivation if we consider her mental health.

The biggest component that increased the likelihood of Farak stealing and using drugs is the intersection of her desired target and the absence of a suitable 
guardian. The crime lab did not properly secure or supervise access to standards. Further, Farak detailed multiple times and occasions in which she was left unsupervised. By Farak's own account, when she worked for another crime lab that had better security measures, she did not attempt to steal or use the drugs in the lab. Therefore, we are left to question whether increased supervision and limited access to a desired target would have decreased the likelihood of these crimes. If this is true, it adds weight to the argument that supervision or the presence of capable guardians does deter criminal behavior.

In addition to the lack of capable guardian, it could be argued that there was a lack of place managers (Felson, 1995). Farak's own supervisor can be considered both a guardian and a place manager. He was tasked with managing the lab regarding employee behavior, ordering standards, and keeping track of what was happening in the lab. In this regard, he is a place manager. He was also tasked with supervising the employees - looking for suspicious behavior and acting as a guardian for the lab. In this manner, he was both a place manager and a guardian.

The Sonja Farak case is a great application of Routine Activity Theory. This does not mean it is the only applicable theory. For example, when reading her court transcript, there are elements of Sykes and Matza's (1957) Techniques of Neutralization Theory. At times, she denies both injury to the victims (the perceived offenders) and at the same time denies harm. She argued she never convicted an innocent person because she only stole "real" drugs from evidence. If the drug gave her the desired effect, then the perceived offender was guilty of possessing a narcotic; therefore, her testing in the lab was correct. In all, she did not see the harm in testifying in court against perceived offenders or physically testing evidence because she knew they were guilty because she tried the drug herself. This makes for a unique application of the Techniques of Neutralization; however, appeal to higher loyalties and condemnation of the condemners did not seem as prevalent in her grandy jury testimony. Overall, it would be interesting to see further application of theory applied to the Farak scandal.

\section{Conclusion}

The Farak drug scandal adds to the discussion of how everyday citizens can function and blend into society and still commit criminal behavior (Long, 2021). As we examine criminal behavior, we need to be aware that there is a thin line that separates who is criminal and who is not criminal. Many times, this line is simply who gets caught. If Farak did not make a mistake by hiding fake drugs to substitute into the drug evidence she could still be analyzing drugs for a state crime lab in Massachusetts.

Though the Routine Activity Theory allows for us to understand how every day, routine scenarios can increase likelihoods of criminal behavior, there are a few limitations to this research. First, we should cautiously apply Routine Activity Theory to this behavior as the testimony provided is given in retrospect. Fa- 
rak had time to prepare and knew how to phrase certain aspects of her behavior. Had this been immediate, her responses might have differed, and this could change the applicability of the theory. Secondly, when viewing the transcript, it seemed as though the State was trying to emphasize the lack of supervision and quality control of the state crime lab. This made it easy for Farak to place blame for the absence of suitable guardians. As with the first limitation, it may be questioned if this was Farak's belief at the very beginning. Lastly, at times the application of Routine Activity Theory seems simplistic; the three components of the theory are easily satisfied. Though straightforward, researchers have come to terms with using the theory to help understand likelihoods of victimization and the application of individual offending.

\section{Acknowledgements}

This research is self-funded. The author confirms there are no conflicts of interest involved with any parties in this research study.

\section{Conflicts of Interest}

The author declares no conflicts of interest regarding the publication of this paper.

\section{References}

Becker, D. (2020). Judge's Ruling Linked to the Disgraced Chemist May Pave Way to Reopen Thousands of Mass. Cases. WNUR News. https://www.wbur.org/news/2020/09/14/sonja-farak-sutton-case-boston-hinton-lab

Bowen, G. (2009). Document Analysis as a Qualitative Research Method. Qualitative Research Journal, 9, 27-40. https://doi.org/10.3316/QRJ0902027

Cohen, L., \& Felson, M. (1979). Social Change and Crime Rate Trends: A Routine Activity Approach. American Sociological Review, 44, 588-608. https://doi.org/10.2307/2094589

Eck, J., \& Madensen, T. (2015). Meaningfully and Artfully Reinterpreting Crime for Useful Science: An Essay on the Value of Simple Theory. In M. Andersen, \& G. Farrell (Eds.), The Criminal Act: The Role and Influence of Routine Activity Theory (pp. 5-18). Palgrave Macmillan. https://doi.org/10.1057/9781137391322 2

Felson, M. (1986). Linking Criminal Choices, Routine Activities, Informal Control, and Criminal Outcomes. In D. B. Cornish, \& R. V. Clarke (Eds.), The Reasoning Criminal: Rational Choice Perspectives on Offending (pp. 119-128). Spring-Verlag. https://doi.org/10.1007/978-1-4613-8625-4 8

Felson, M. (1995). Those Who Discourage Crime. In J. Eck, \& D. Weisburd (Eds.), Crime and Place. Crime Prevention Studies (pp. 53-66). Criminal Justice Press.

Felson, M., \& Cohen, L. (1980). Human Ecology and Crime: A Routine Activity Approach. Human Ecology, 8, 389-405. https://doi.org/10.1007/BF01561001

Grand Jury (2015). Hearing before Hampshire County. https://www.documentcloud.org/documents/4347254-Ware-253-Farak-GJ-Transcript9-16-15.html

Haynie, D. L., \& Osgood, W. D. (2005). Reconsidering Peers and Delinquency: How Do 
Peers Matter? Social Forces, 84, 1109-1130. https://doi.org/10.1353/sof.2006.0018

Haynie, D. L. (2001). Delinquent Peers Revisited: Does Network Structure Matter? American Journal of Sociology, 106, 1013-1057. https://doi.org/10.1086/320298

Kennedy, L. W., \& Forde, D. R. (1990). Routine Activities and Crime: An Analysis of Victimization in Canada. Criminology, 28, 137-151. https://doi.org/10.1111/j.1745-9125.1990.tb01321.x

Lauritsen, J. L., Sampson, R., \& Laub, J. (1991). Victimization among Adolescents. Criminology, 29, 265-289. https://doi.org/10.1111/j.1745-9125.1991.tb01067.x

Long, R. (2021). Who Is Sonja Farak and What Is Her Drug Scandal? Vizaca. https://www.vizaca.com/sonja-farak-now

McNeeley, S. (2015). Lifestyle-Routine Activities and Crime Events. Journal of Contemporary Criminal Justice, 31, 30-52. https://doi.org/10.1177/1043986214552607

Messner, S., \& Blau, J. (1987). Routine Leisure Activities and Rates of Crime: A Macro-Level Analysis. Social Forces, 65, 1035-1051. https://doi.org/10.2307/2579022

Musgrave, S. (2019). The Chemists and the Cover-Up. Reason. https://reason.com/2019/02/09/the-chemists-and-the-cover-up

Osgood, W. D., Wilson, J. K., O’Malley, P. M., Bachman, J. G., \& Johnson, L. D. (1996). Routine Activities and Individual Deviant Behavior. American Sociological Review, 61, 635-655. https://doi.org/10.2307/2096397

Osgood, W. D., \& Anderson, A. L. (2004). Unstructured Socializing and Rates of Delinquency. Criminology, 42, 519-549. https://doi.org/10.1111/j.1745-9125.2004.tb00528.x

Patton, M. Q. (2002). Qualitative Research and Evaluation Methods. Sage.

Sampson, R. J., \& Lauritsen, J. L. (1990). Deviant Lifestyles, Proximity to Crime and the Offender-Victim Link in Personal Violence. Journal of Research in Crime \& Delinquency, 27, 110-139. https://doi.org/10.1177/0022427890027002002

Savard, D. (2018). A Routine Activity Approach: Assessing Victimization by Gender in Transit Environments and Other Public Locations. Advances in Applied Sociology, 8, 56-75. https://doi.org/10.4236/aasoci.2018.81004

Schreck, C. J., \& Fisher, B. S. (2004). Specifying the Influence of Family and Peers on Violent Victimization: Extending Routine Activities and Lifestyles Theories. Journal of Interpersonal Violence, 19, 1021-1041. https://doi.org/10.1177/0886260504268002

Small, G. (2020). Sonja Farak from "How to Fix a Drug Scandal” Has Been Out of Prison for Years. Bustle.

https://www.bustle.com/p/where-is-sonja-farak-now-the-how-to-fix-a-drug-scandal-su bject-keeps-a-low-profile-22678003

Sykes, G., \& Matza, D. (1957). Techniques of Neutralization: A Theory of Delinquency. American Sociological Review, 22, 664-670. https://doi.org/10.2307/2089195

Tillyer, M. S., \& Eck, J. E. (2011). Getting a Handle on Crime: A Further Extension of Routine Activities Theory. Security Journal, 24, 179-193. https://doi.org/10.1057/sj.2010.2

Wallace, J. M. Jr., \& Bachman, J. G. (1991). Explaining Racial/Ethnic Differences in Adolescent Drug Use: The Impact of Background and Lifestyle. Social Problem, 38, 333-357. https://doi.org/10.2307/800603

Wilcox, P., Tillyer, M. S., \& Fisher, B. S. (2009). Gendered Opportunity? School-Based Adolescent Victimization. Journal of Research in Crime \& Delinquency, 49, 245-269. https://doi.org/10.1177/0022427808330875 